\title{
空気輸送管中を移動する小䌉維塊の測定につにて
}

\author{
椟皇大学工学部 \\ 黒崎新也・近田富士雄 \\ 伊藤 元貫

\section{ON THE MEASUREMENT OF SMALL FIBER ASSEMBLIES FLYING IN PNEUMATIC CONVEYOR PIPE.}

By Shinya Kurosaki, Fujio Konda and Motoyoshi Ito

(Faculty of Engineering, Gifu University, Kakamigahara City, Gifu Prefecture, Japan)

In the present study, an apparatus for the continuous measurement of the size and the interval of fiber assemblies fiying at a high-speed air flow was first devised and its performance was investigated. Further, as an example of applying it in practice, the behavior of assemblies was measured by separating a sliver continuously by suction.

It is believed that by developing this study further, the basic information will be obtained on the clustering condition of fibers, which is importont in the pneumatic spinning, pneumatic conveyance, carding, etc.

The results obtained from this experiment are summarized as follows :

(1) It is possible to measure the size of fiber assemblies flying with high speed by use of a. capacitance type detector (Fig. 1).

(2) This apparatus enables one to detect a cluster composed of about $5 \sim 6$ filaments of $3 \mathrm{D}, 2$ in-cut viscose fiber.

(3) When a sliver, going out from the front roller after roller drafting is separated by suction, the intervals of separation is distributed nearly in accordance with an exponential distribution. The number of assemblies separated per unit time is subjected to a Poisson's distribution. The size of assemblies can be found from the average time intervals of the separation.

(4) The larger the roller draft ratio and the faster the suction speed, the more easily the sliver is separated into smaller assemblies.

(Received September 11, 1968)

\section{1. 緒言}

徒来，紡紿工程における空気流の利用は開綿・綿熄の 空壆输送などの分野で行なわれてきた。とく火近時、空 筑流を利用したオープンエンド紡績法が開発されるにお よんでこの方面での研究 ${ }^{1-5}$ が進められている。しか しながら空気流中を移動する㵶維塊の大きさを連続的に 测定した結果ははとんど見当らない。

本研究では，坴気転送管中を高速空気流とともに 移動する織維塊の大きさ，括上び䔟動状態を連続的に測 定する装置を作製し，その性能を倹討した。

さらに，実際への適用例として，ドラフト部のフロン トかーラ近くに吸引管を設置し、ドフトされた粗采を 連続的に吸引，分離してタフトの挙動を求めた。

本研究をさらに発展させることによって，品気流利用 精紡，空気翰送，棉塊の解钴などて間題となる絵維の集

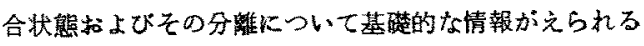
と考えられる。

\section{2. 実験装置・方法}

第 1 図比本研究に使用した装置の概要を示す。装置は 全体として綎型をして如り，左下の排風機 Eで空気を吸 引する。䥫䧽塊は右下万から投入され，大きさ，速度測 定部を通過して㛃風機に道かれる。

チニーブ内の空気速度はスライダックTによる電王の 変化，すなかち排風機の回転数変化怙よびハイバスのハ ルブVの開度を変化させてかなり広籍国に変克ることが できる。風速の那定は必要に応してて注射針ビト一管P柆 よび水柱マノメータMによって求められる。実際に緎維

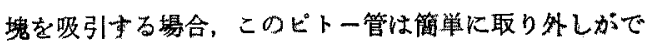
きるよらになている。

後速するが，根引部にドラフト等置をとりつけ，フッ 


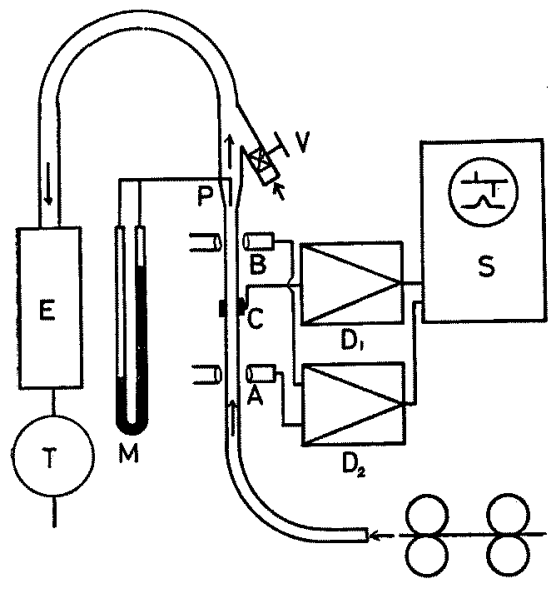

Fig. 1. Experimental appratus. Fibers sucked in from the inlet of tube move through the tude and their velocity is measured at $A, B$ and their size at $C$.

$A, B$; Photo transistor $C$ : Condenser $D_{1}$, $\mathrm{D}_{3}$ : Amp. $\mathrm{E}:$ Air exhauster $\mathrm{M}:$ Manometer $P$ : Pitot tube $S$ : Dual beam synchroscope $T$ : Slidac $V:$ Valve

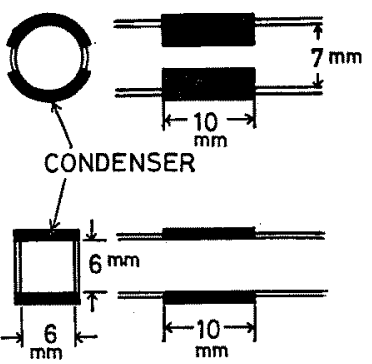

Fig. 2. Two kinds of capacitance detector.

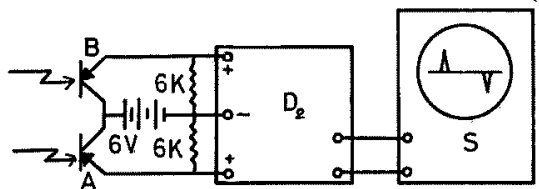

Fig. 3. Apparatus for measuring velocity of fiber assemblies.

A, B : Photo transistor $\quad D_{2}$ : Differential amp $S$ : Synchroscope

ントローラから送り出されるスライバを眼引，分離させ ながら連続的にタフトの大きさを測定することが可能で ある。

蟣維塊の大きさの検出部は第 2 図に示すように，一辺 が $6 \mathrm{~mm}$ の角型和上び亩径 $7 \mathrm{~mm}$ の丸型の透明アクリル 樹脂管にコンデンサCを取りつけたるのである。コンデ
ンサの周国には外乱の影整を防ぐためシールドが設けて ある。繊維塊がコンデンサ間を通過した場合，静電容量 の变化として検出, 增幅し, シンクロスコーブSにて測 定する。

速度の湘定 ${ }^{6)}$ は 2 対の投 - 受光器 $A, B$ を第 1 図のよ らに設唯する。受光器には同規格のフォト・トランジス タが入っでり，これを第 3 图の上5に出力を害勘アン プ $\mathrm{D}_{2}$ に入れて就く。両方のフォト・トランジスタに光 が当っているときは信号が平衡状態にすり出力は0，一 方の光線がさ支ぎれることによってバンスがくずれ 出力信号があらわれる。A，Bでの信号は逆方向のパル スとして表われるよ5になっているので信号の区別に便 利である。この信号の時間差および受光器間の距離から 移動速度が求められる。

な扮， $\mathrm{D}_{1} ， \mathrm{D}_{2}$, フォト・トランジスタ拈よびシンクロ スコープの周波数特性はそれぞれ，100，200，10蛒よ

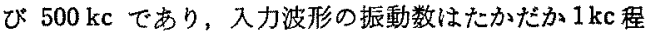
度であるから測定可能である。

以上のような方法でコンデンサからの信号扎よび受光 器からの信号を 2 現象シンクロスコープ Sで同時に剆定 できるようにした。

\section{3. 実験結果と考察}

\section{$3 \cdot 1$ 空曼輸送管内における風速}

ハイパスのバルブ開度变化，およびスライダックによ

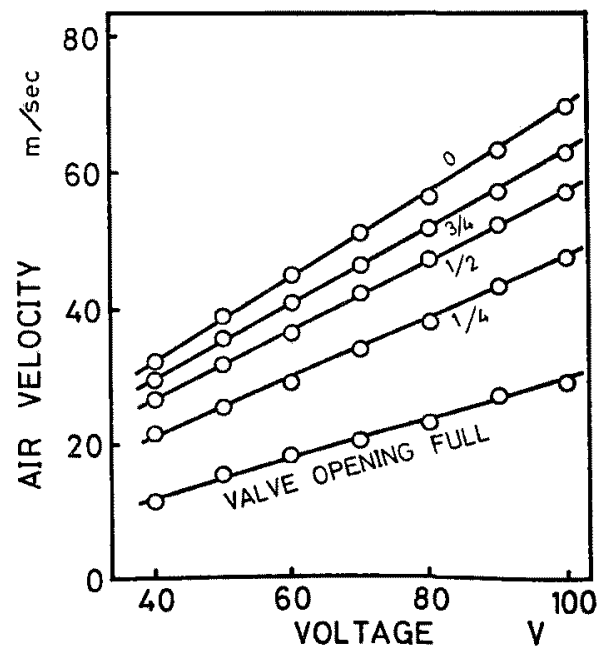

Fig. 4. Relation between the applied voltage to the air exhauster and the air velocity in the tube. The uppermost and the lowermost straight lines correspond respectively to the cases when the valve is perfectly closed and opened. 
る電圧の変化と風速の関係を第 4 図に示す。図から管内 で $10 \sim 70 \mathrm{~m} / \mathrm{sec}$ の範囲の任意の風速がえられる。ここ で限界レイノルズ数 $R_{e}$ を23107) と沶いて

$$
R_{e}=u D / \gamma
$$

から篔流をなす風速 $u$ を求めてみる。（1）式に $D=6 \times$ $10^{-3} \mathrm{~m}$ (チューブ径)， $\quad r=1.44 \times 10^{-5} \mathrm{~m}^{2} / \mathrm{sec}$ (空気動粘 性係数）を代入すると $u=5.5 \mathrm{~m} / \mathrm{sec}$ となる。本装置で えられる風速は $5.5 \mathrm{~m}$ 以上であり，すべて乱流領域であ る。この場合，ピト一管は第 1 図に示したよ5に㵶維塊 の大きさ，および速度などの測定部の近くに取り付、 てあるので，この付近での速度を測定することになる。 以後, 空気速度の影響を検討する場合には, この部分で 測定した空気速度を意味する。

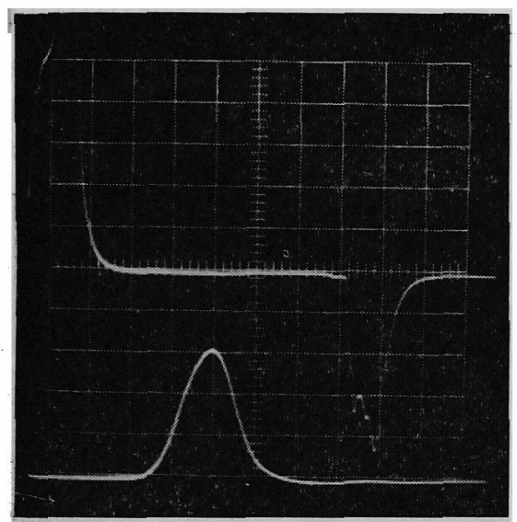

Fig. 5. An example of waveform appearing on the synchroscope. The upper and the lower curves show respectively signals coming from photo-transistor and from condenser. (sweep $2 \mathrm{msec} / \mathrm{div}$ )

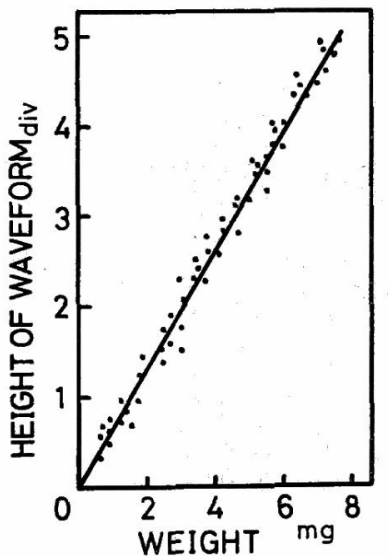

Fig. 6. Relation between the weight of sliver of same length $(15 \mathrm{~mm})$ and the height of waveform on the synchroscope.
3.2 䋨維塊の大きさ, 速度の測定

第 5 図は粗紡機上り，1.5S の粗系(ビスコース)を 15 $\mathrm{mm}$ に切断して吸引した場合, シンクロスコープに表わ れる波形を示したものである。上はフォト・トランジス タからの信号で検出器 A・Bを通過したときのパルスで ある。下はコンデンサの容量変化を示す。ここでュンデ ンサ間を通過する絨維塊の形状，および重量と波形の関 係について検討する。

粗系の長さを $15 \mathrm{~mm}$ と一定にし, 重量を変えて波形 の高さの関係を求めると第 6 図のような直線関係がえら れる。コンデンサ幅 $10 \mathrm{~mm}$ に対して試料長を $15 \mathrm{~mm}$ と一定にしたが，試料長が变化した場合の結果を第 7 図 に示す。図は太さがほぼ同じで，異なる長さに切断した 粗系を吸引させた場合, 波形の高さと試料の重量との関

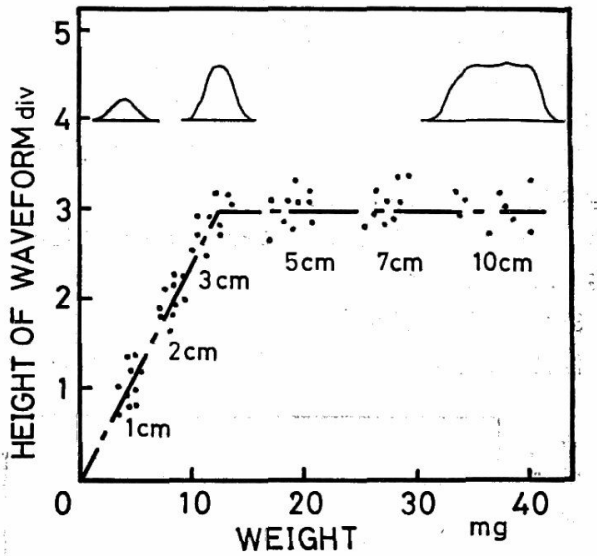

Fig. 7. Relation between the weight of sliver and the height of waveform on the synchroscope.

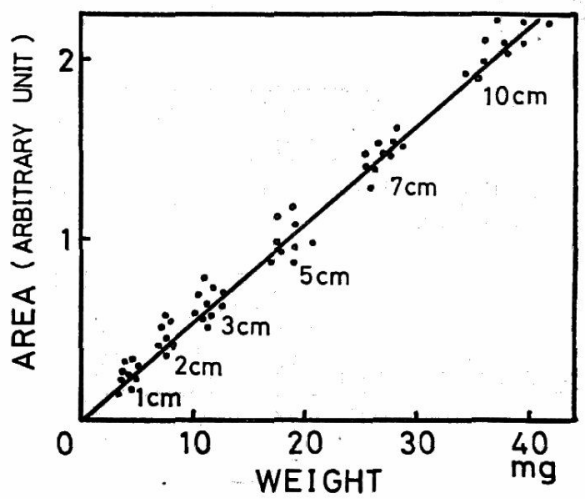

Fig. 8. Relation between the weight of sliver and the area of waveform on the synchroscope, in which linearity is observed. 
係を示したものである。試長が $3 \mathrm{~cm}$ 程度までは重量と 波形の高さはほぼ直線的関係を示すが， $3 \mathrm{~cm}$ より長い 場合には記録される高さは変化しないことがわかる。検 出器としてコンデンサには限界があり、ニンデンサより ある程度離れた場所では静電容量に変化をおよぼさな い。このよ5に波形の高さでは長さに大きな変動をるつ 塊りの大きさ，重量は比較できないことがわかる。一方 掃引速度を速くして容量変化の波形を示せば第 7 図のよ 5 になる。 $3 \mathrm{~cm}$ 以上の場合は波形の高さは変わらず時 間軸方向に長くなる。そこで波形の面積と重量の関係を 図示すれば第 8 図の関係がえられる。

分織された小織維塊の移動速度についてであるが，以 下の実験で通常観湘される $2.0 \mathrm{mg}$ 以下の大きさの塊り ではほぼ等速で，空気速度の 50～60\% をとるが，まれ 飞観測される $5 \mathrm{mg}$ 以上の大きな㵶維塊についてはいら じるしく速度を減じる傾向がある。これについての実験 結果を第 9 図に示す。30４0mg で風速の $20 \%$ 程度に なる。

以上のように長さが一定の試料ならば波形の高さで大 きさを比較しうるが，長さが種々異っている場合には波 形の面積を求めることによってそれぞれの瀻維塊の大き さがほぼ推定できる。

\section{3 実際への適用例}

作製した実験装置を用いて具体的応用例について実験

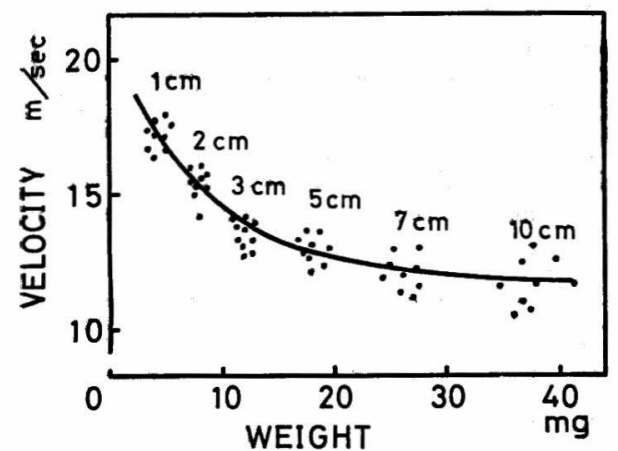

Fig. 9. Relation between the weight and velocity of sliver.

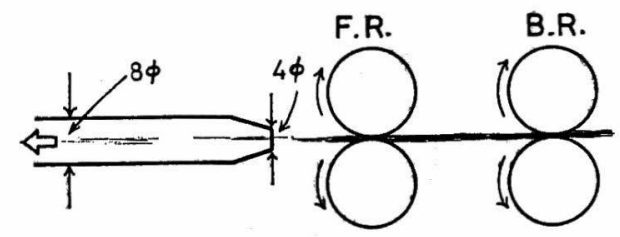

Fig. 10. A part of experimental apparatus. After being drafted by roller, sliver is separated in the suction tube and transported.
検討した。第 10 図のようにドラフト装置のフロントロ ーラ近傍にガラス製の吸引管を設置し， $3 \mathrm{D} ， 2$ in カッ トのビスコース粗系 $1.5 \mathrm{~S}$ をラ゙ラフトし, 吸引分離され たタフトの大きさを測定した。ドラフト比, フロントロ 一ラ送り速度および吸引速度をそれぞれ 3 段階選び分離 状態に㸝よぼす影響を測定した。

ドラフト比 8.10 , 風速 $67 \mathrm{~m} / \mathrm{sec}$, フロントローラ送

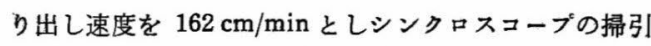
速度を $1 \mathrm{msec} / \mathrm{div}$ と速くして撮影した結果例を第 11 図, 第 12 図に示す。図から大きな波形, 小さな波形が みられる。さらに周期, 振幅の小さい波形は測定器の雑 音である。な拉，タフトの通過した信号波形が重なって いるのは何回も掃引しているためである。3.2 で述べた ように面積によって大きさの比較ができることを知っ た。そこで、数多くの波形を撮影し，面積の分布を求め た。結果を第 13 図に示す。一方, 既知の形状, 重量の タフトを吸引させて, その面積を求め,すでに行なった

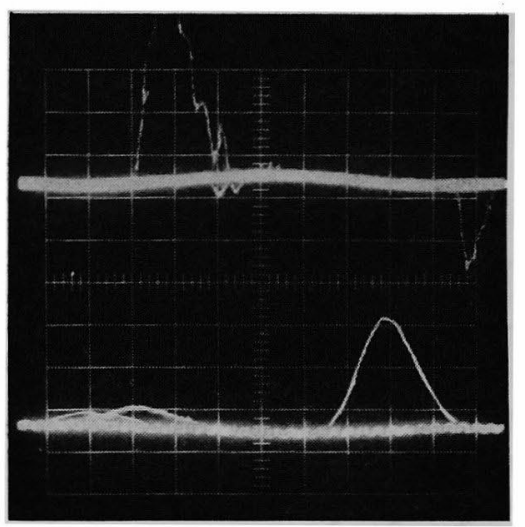

Fig. 11. An example of waveform appearing on the synchroscope. (sweep $1 \mathrm{msec} / \mathrm{div}$ )

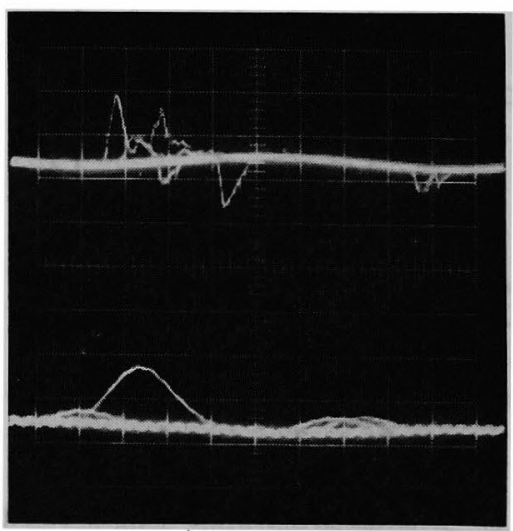

Fig. 12. An example of waveform appearing on the synchroscope. (sweep $1 \mathrm{msec} / \mathrm{div}$ ) 


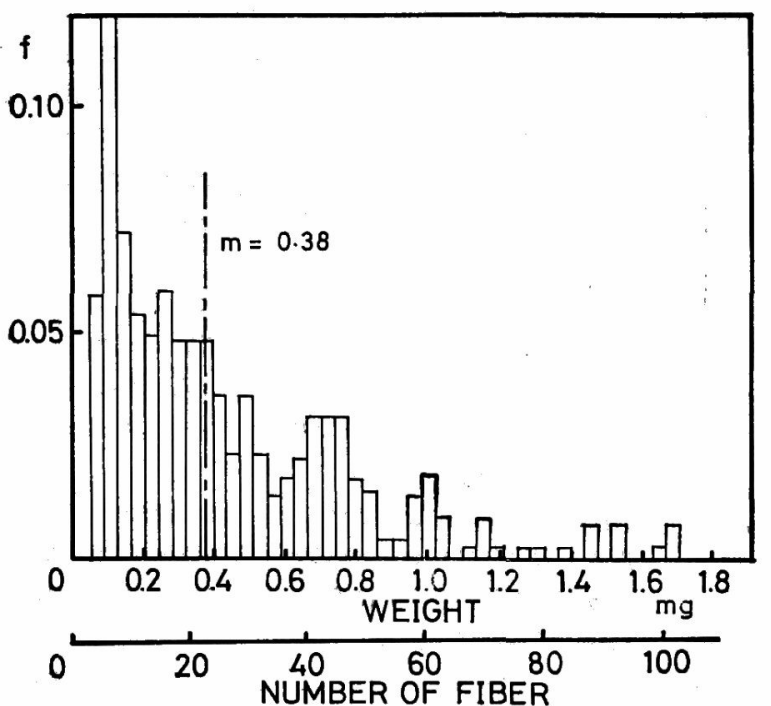

Fig. 13. Distribution of weight (or number of pieces) of separated assemblies.

実験のそれそれのタフトの重量をしることがでさる。第 13図の横軸岏このよ5にして求めた重量と，これから換 算した織維本数を示してある。この結果から,ドラフト

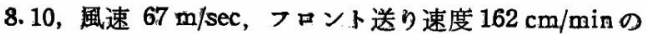
条件で分離したタフトの平均の大きさは約 $0.38 \mathrm{mg}$, 本 数にして 23 本程度であり, 5〜10 本の塊りが多いこと を示す。このような吸引分離方法では集団分離が主体で あって個々の分離は少い。

つぎにシンクロスコープの掃引速度を $0.2 \mathrm{sec} / \mathrm{div}$ と 括とくして分離移動している様相を示したのが第 14 図 である。上方の信号はフォト・トランジスタからの信号 で, 下はコンデンサからの信号である。パルスは㵶維集

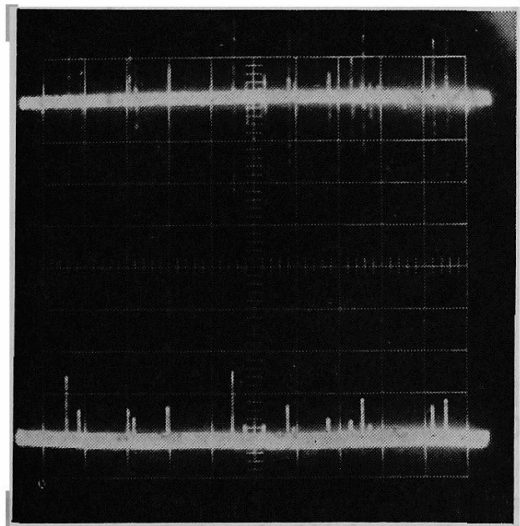

Fig. 14. An example of pulse appearing on the synchroscope. (sweep $0.2 \mathrm{sec} / \mathrm{div}$ )
団がコンデンサ間を通過したことを意味する。 フォト・トランジスタからの信号とコンデンサ からの信号がそれぞれ対応をなしている。繊維 束が分離する場合，本実験の条件では空気速度 がおそい場合を除いて長いタフトはほとんどな いので高さはそのままタフトの大きさを示する のと考皃てょい。

1 秒間に分離するタフトの個数分布を第15図 当 の○゙示す。この分布の平均値は 3.4 である。 一方, 平均値が 3.4 のポアンン分布 $P(x, 3.4)$ を実験で示すと図のようになり，単位時間に分 離するタフトの個数分布はポアソン分布にした がうと考えてよい。この分布は風速，フロント ローラ送り速度，ドラフト比によって左右され る。

タフトが分離する時間間隔の分布を求めると 第 16 図に示す度数分布をえる。

ここで, 時間間隔の分布をつきに示す指数分 布8)とする。

$$
\rho(\tau)=m \exp (-m \tau)
$$

たたし，mは単位時間に分離するタフトの個数であり， ては時間間隔である。戦位時間（1/10秒）に分離する個 数は第 15 図の結果から 0.34 個であるから $m=0.34$

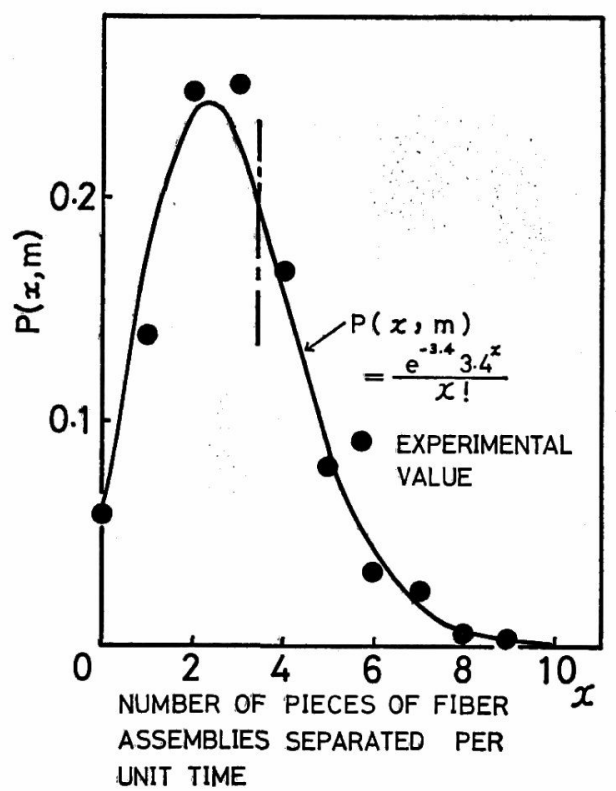

Fig. 15. Distribution of the number of pieces of assemblies separated per unit time. It is approximated to the Poisson's distribution. 


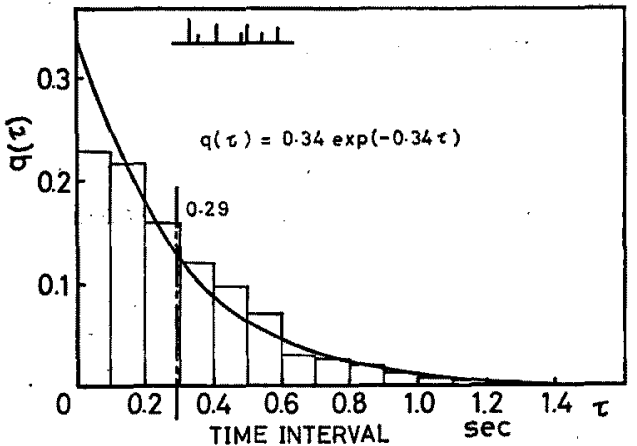

Fig. 16. Distribution of time interval of separated assemblies. The distribution is nearly exponential.

\section{として計算した結果を実線で示す。}

このよ5に単位畤間に分離する個数がポアンン分布を 示し，しか子時間間隔が指数分布を示すことの両者から 㵶唯束はランダムに分離していると推定される9。

また、フトントローラから送り出される量は1.33mg/ $\sec$ であり，タフトの分離する時間間隔の平均が 0.29 sec であることから，分詴する維維束の大ささを計算す ると $0.38 \mathrm{mg}$ を得る。これは波形の面積を求めてタフト 重量を計算した第 13 図から光た結果と同じ值を示す。

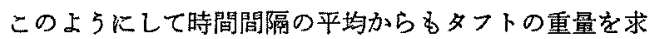
めることか゚できる。
条件を变えると単位時間に分離する個数分布，特よび 時間間隔の分布が変化する。吸引速度，ドラブト比， フ ロントローラ送り速度を觉化させた場合，単位時間に分 離するタフトの個数分布を第 17 図に示す。すなかち風 速が速くなるにつれて平均値は大きく，いいがれば数 多く分離するよ5になる。ドラフト変化には一定の傾向 が認められない。

またフフロントローラ送り速度が大きくなるにつれて 分谝隹する個数が多くなることを示しているが，供給量が 多くなるための当然の結果であると考えられる。具体的 なタフトの大さと条件についての関係は第 19 図で示 してある。

，時間間隔の分布をまとめて示したのが第 18 図である。 風速，およびフロントローラ送り速度が速くなるにつれ て分布は間隔の小さい注万人移行する。これは第 17 图 に対応する結果である。

第 18 图第 17 図から, 吸引速度、ドラフト比,フロン トローラ速度などの条件が分離するタフトの大きさに椋 よばす影響を計算した。結果を第 19 図に示す。図の綎 軸はタフトを構成する戴維本数に換算してある。空気速 度を速く、ドラフト比を大きくするにつれてタフトは小 さくなり，ファントローラ送り出し速度を增すにつれて 大きくなる。これらの結果から，粗系をなへく小さく分 離するためには，吸引速度，怙よびドラフトを大きく、フ ロント送り出し速度を小さくすればよいと考えられる。

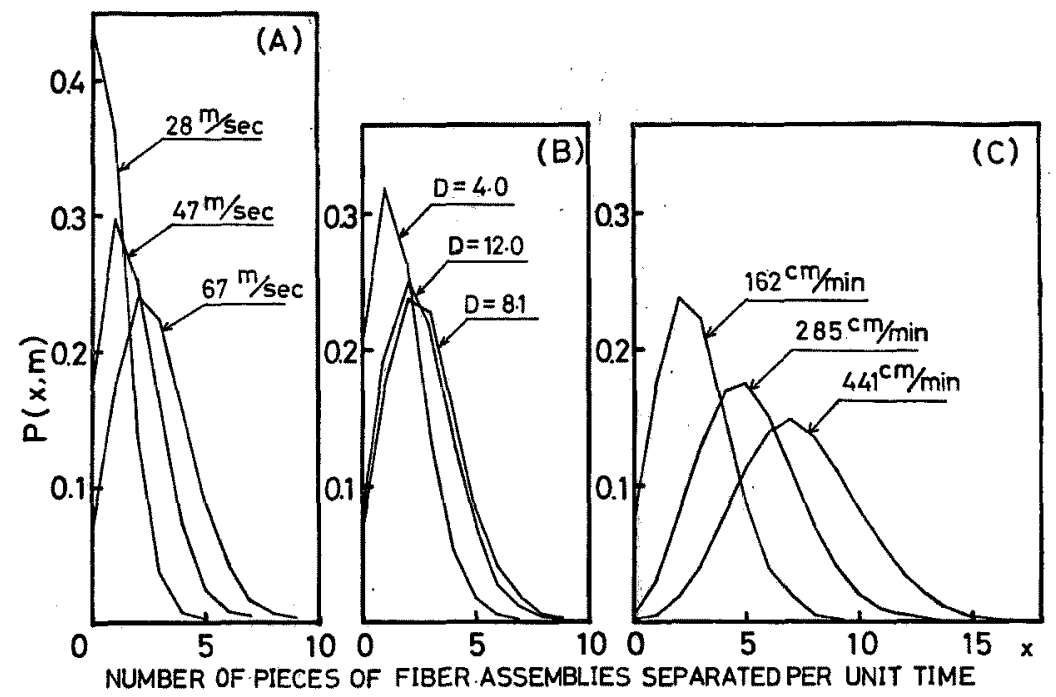

Fig. 17. Relation between the drafting conditions and the number of pieces of assemblies separated per unit time. The effects of (A) air velocity, (B) draft ratio and (C) front roller delivery speed. 
(37)
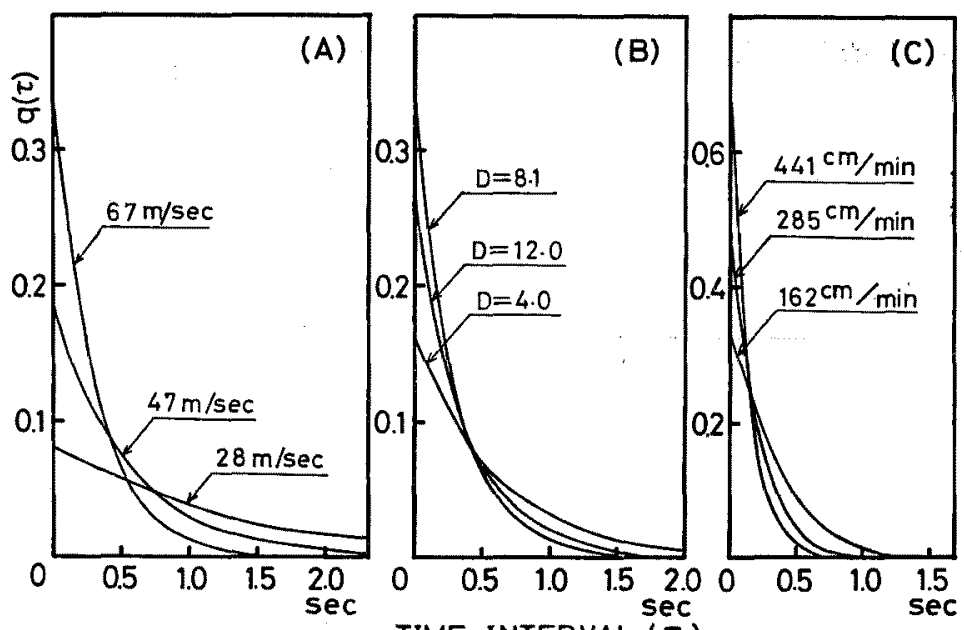

TIME INTERVAL $(\tau)$

Fig. 18. Relation between the drafting conditions and the distribution of time interval of separated assemblies. The effects of (A) air velocity, (B) draft ratio and (C) front roller delivery speed.
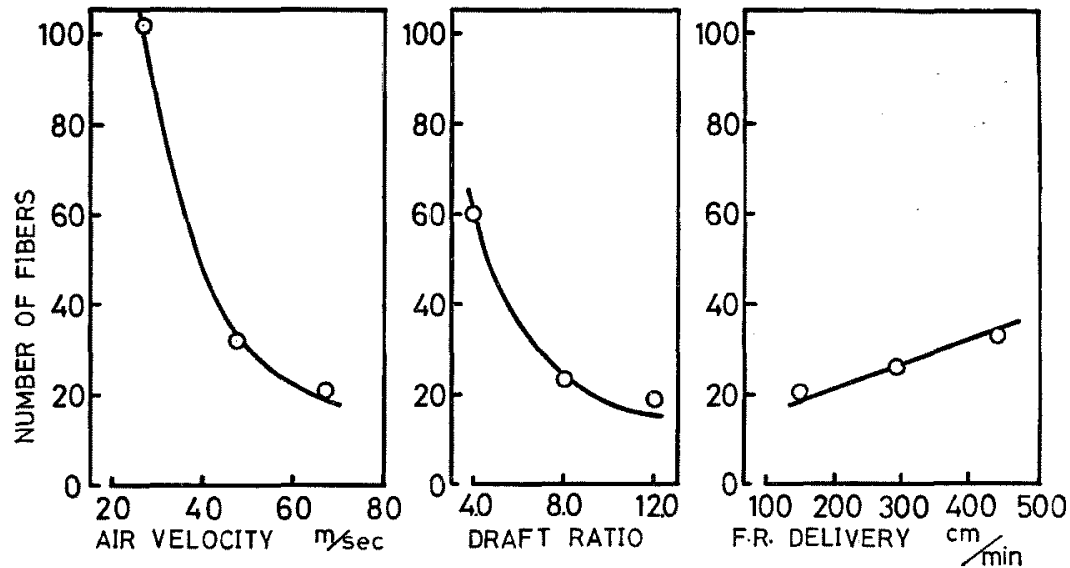

Fig. 19. Relation between the drafting conditions and the number of fibers composing assemblies.

\section{4. 結言}

空気輸送管中を高速で移動する㵶維塊の大きさ，括上 びその移動举動を連続的㓫測定する装置を試作し，性能 の换討と実際への適用について実験した結果，つぎの結 論をえた。

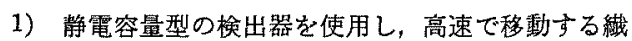
稚㙞の大ささを测定することが可能である。

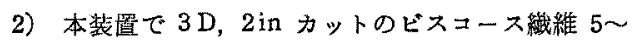
10 本程度の集団紊で検出でさる。

3）ローラドラフトを行ないながらフロントサーラを
出た織維束を吸引分離した場合，分離する時間間隔の分 布は经洼指数分布にしたがう。また，単位時間に分離す るタフトの個数分布はポアソン分布にしたがう。繊維束 が分離する時間間隔の平均を求めることによって塊りの 大きさがかる。

4）ローラドラフト比が大きい㾁ど，吸引空気速度が 大きいほど瀻赤束は小さな集団に分離しやすい。

本研究の一部は文部省科学研究費 (総合研究)により 行ったもので, 総合研究珼任者柬京工大石川章一教授に 深く感謝与る。た本報告は昭和 43 年度㵶維学会春期 研究発表会（東京教育会館）で発表したものをまよめた 
ものである。

実験にこ協力をいただいた横井輝之，後藤英之両氏に 感謝する。

文献

1) 鈴木，小林；織機誌，21，1（1968）

"l " ; 紻維工学, 20, p. 888 (1967)

2）清水，井戸，武智；縅維工学，20，p. 845(1967)

3）福多；緒維工学，20，p. 846 (1967)
4）鳴海，野铝，春山；昭和 43 年練機学会春期発表 会前刷

5）宇野，塩見，嶋田；

6) 前揭 1)

7) 原田; 流体の力学 (槙書店), p. 116 (1965)

8）宮脇；雑音解析（朝倉畫店），p. 40（1961）

9）W.フェラー藷, 河田袂；確率論と乞の応用（紀 伊国屋書店)，p. 565 (1966) 